Prepared for the U.S. Department of Energy

under Contract DE-AC05-76RL01830

\title{
Wind Monitoring Report for Fort Wainwright's Donnelly Training Area
}

AC Orrell

DR Dixon, Program Manager

January 18, 2011

\section{Pacific Northwest}

NATIONAL LABORATORY

Proudly Operated by Battelle Since 1965 


\title{
DISCLAIMER
}

This report was prepared as an account of work sponsored by an agency of the United States Government. Neither the United States Government nor any agency thereof, nor Battelle Memorial Institute, nor any of their employees, makes any warranty, express or implied, or assumes any legal liability or responsibility for the accuracy, completeness, or usefulness of any information, apparatus, product, or process disclosed, or represents that its use would not infringe privately owned rights. Reference herein to any specific commercial product, process, or service by trade name, trademark, manufacturer, or otherwise does not necessarily constitute or imply its endorsement, recommendation, or favoring by the United States Government or any agency thereof, or Battelle Memorial Institute. The views and opinions of authors expressed herein do not necessarily state or reflect those of the United States Government or any agency thereof.

\author{
PACIFIC NORTHWEST NATIONAL LABORATORY \\ operated by \\ BATTELLE \\ for the \\ UNITED STATES DEPARTMENT OF ENERGY \\ under Contract DE-AC05-76RL01830
}

Printed in the United States of America
Available to DOE and DOE contractors from the Office of Scientific and Technical Information,
P.O. Box 62, Oak Ridge, TN 37831-0062;
ph: (865) 576-8401
fax: $(865)$ 576-5728
email: reports@adonis.osti.gov

\begin{abstract}
Available to the public from the National Technical Information Service, U.S. Department of Commerce, 5285 Port Royal Rd., Springfield, VA 22161 ph: (800) 553-6847 fax: $(703) 605-6900$ email: orders@ntis.fedworld.gov online ordering: http://www.ntis.gov/ordering.htm
\end{abstract}

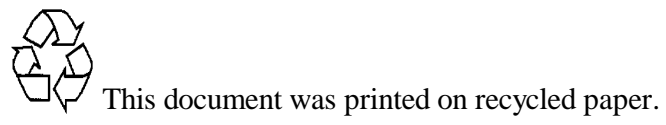


PNNL-20127

\section{Wind Monitoring Report for Fort Wainwright's Donnelly Training Area}

AC Orrell

DR Dixon, Program Manager

January 2011

Prepared under Contract DE-AC05-76RL01830

Pacific Northwest National Laboratory

Richland, Washington 99352 


\section{Executive Summary}

Using the wind data collected at a location in Fort Wainwright's Donnelly Training Area (DTA) near the Cold Regions Test Center (CRTC) test track, Pacific Northwest National Laboratory (PNNL) estimated the gross and net energy productions that proposed turbine models would have produced, exposed to the wind resource measured by the meteorological tower (met tower) during the year of measurement at this location. Calculations are based on the proposed turbine models' standard atmospheric conditions power curves, the measured annual average wind speeds, wind shear estimates, and standard industry assumptions.

These basic calculations provide a better understanding of the potential energy production at the met tower location, but do not provide hub-height wind speed estimates for heights above the height of the met tower or long-term energy production expectations.

Wind data was collected for 1 year, from October 2009 to October 2010, at the location with coordinates $\mathrm{N} 63^{\circ} 55.891^{\prime} \mathrm{W} 145^{\circ} 44.762^{\prime}$ '. This location is south and west of the CRTC test track and the western border of this area is the fence that separates DTA land from private land. The collected data indicates that the average annual wind speed is $5.5 \mathrm{~m} / \mathrm{s}$ at a height of $50 \mathrm{~m}$. This means the site has a high Class 1 to a low Class 2 wind resource. A wind resource less than Class 3 is generally considered too low to support economically feasible wind energy projects.

The wind data was collected using a 50-m XHD met tower provided by NRG Systems. This report supplements the annual wind data summary report provided by Det Norske Veritas (DNV), the globally recognized wind energy consulting firm that installed the met tower and conducted the data collection process on behalf of PNNL.

Fort Wainwright should consider the costs and benefits of pursuing a single turbine installation and reuse the met tower in another location.

While the data collection has indicated there is a low wind resource at the CRTC test track location, a 900-kW turbine project there would have marginal economics and may be a possibility. An Energy Conservation Investment Program (ECIP) funded 900-kW turbine that would replace energy purchased from Golden Valley Electric Association (GVEA) provides the best economic potential with a 0.9 savings-to-investment ratio (SIR) and a 17-year payback, given the cost and performance assumptions. The ECIP metrics could improve if the cost of electricity from GVEA has increased since the rate was originally calculated for PNNL's renewable energy assessment report of Fort Wainwright in 2009.

Because sufficient met tower data has been collected at the CRTC test track site, PNNL recommends that Fort Wainwright move the met tower to another location to determine if a stronger wind resource is available somewhere else in the DTA. Two possible options are Windy Ridge and the Black Rapids Training Center. 


\section{Contents}

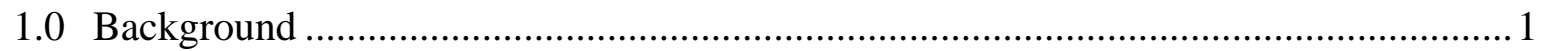

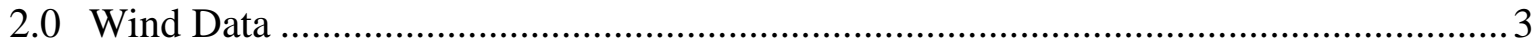

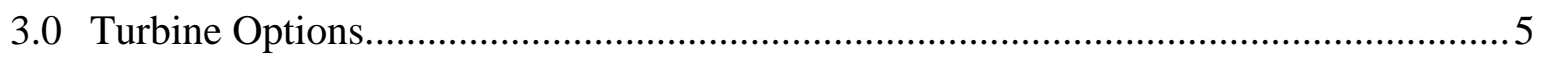

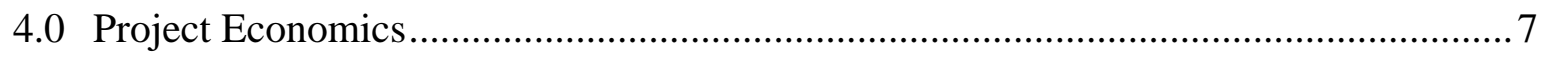

5.0 Delta Junction Wind Farm ............................................................................ 9

6.0 Fort Wainwright Energy Consumption ................................................................... 10

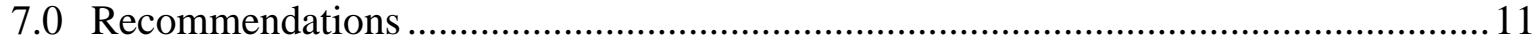

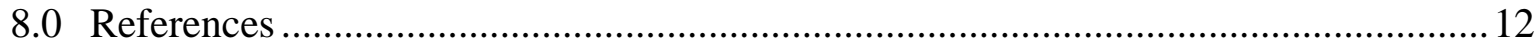




\section{Figures}

Figure 1. Donnelly Training Area Wind Resource .................................................. 2

Figure 2. Met Tower ........................................................................................ 4

\section{Tables}

Table 1. Monthly Wind Speed Averages in meters per second $(\mathrm{m} / \mathrm{s})$............................. 3

Table 2. 100-kW Turbine Energy Production Estimates ................................................... 5

Table 3. 900-kW Turbine Energy Production Estimates ............................................... 6

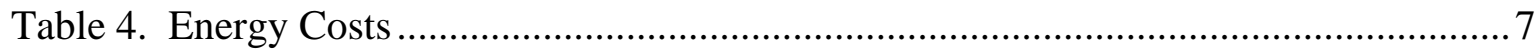

Table 5. Economic Assumptions \& Results ............................................................ 8

Table 6. Delta Junction Wind Farm Energy Production Estimates ................................... 9

Table 7. Fort Wainwright Projected Energy Consumption ............................................ 10

Table 8. Wind Energy Requirements to Meet Goals .................................................... 10 


\subsection{Background}

In November 2008, representatives from Pacific Northwest National Laboratory (PNNL) made a site visit to Fort Wainwright (FWA) to support a renewable energy assessment report of the installation. PNNL submitted a draft of this U.S. Army Installation Management Command (IMCOM) funded report to Fort Wainwright in March 2009 and a final report in October 2009 that recommended a wind resource assessment be conducted for Fort Wainwright's Donnelly Training Area (DTA) to verify the area's exact wind resource (Chvala et al. 2009).

The DTA covers a large amount of land with terrain variations. The renewable energy assessment report originally targeted a site located west of Donnelly Dome, along the southern portion of Windy Ridge adjacent to a telecommunications station operated by AT\&T as the location for the assessment to be conducted.

To perform the wind resource assessment, FWA provided funding to PNNL to site, procure, and install a meteorological tower (met tower) and to provide met tower data collection and analysis services for 1 year. To complete this effort, PNNL worked with Det Norske Veritas (DNV), a wind energy consulting firm.

Actual met tower data is needed to verify the exact wind resource at the site of any potential wind energy project. The potential inaccuracy of the Alaska wind resource map as a result of incomplete data for the area and the limitations of modeling further force the necessity. Strong, but inconsistent, Chinook winds from the south may skew the average annual wind speed indicated by the wind resource map. Met tower data provides a precise assessment of the wind resource.

In July 2009, representatives from PNNL and DNV met with representatives from Donnelly Training Area's Range Control, the Cold Regions Test Center (CRTC), and Fort Wainwright's Department of Public Works to discuss possible met tower site locations. Three potential locations were identified and visited: Option 1 is a site east of the Alyeska pipeline, and west of Dome Road and a creek; Option 2 is south and west of the CRTC test track, along the eastern border of nonmilitary land; and, Option 3 is the southern portion of Windy Ridge, near the AT\&T tower. These sites are marked in Figure 1.

Options 1 and 3 both had numerous obstacles. Option 1 presented low to no impact to Range Control, but access to the site would have required permission from Alyeska and the area has a low perceived wind resource. Option 3 has the highest wind resource of all the sites considered, according to the wind resource map, but is adjacent to restricted air space and existing communications equipment.

Based on the expected wind resource alone, PNNL initially recommended installing the met tower on the southern end of Windy Ridge (Option 3). However, because of the potential mission conflicts at this site expressed by CRTC representatives, expected delays in obtaining permits and approvals, and the limited construction season available for met tower installation, PNNL did not recommend that the met tower be installed there at that time. 
The selected site (Option 2), near the CRTC test track, was chosen because of its lack of mission conflicts to CRTC or Range Control. However, the CRTC meteorologist, Craig Egeland, indicated that the site probably had a low, but consistent wind resource. Therefore, PNNL recommended that if 1 year of data at Option 2 proved that the wind resource there was not feasible, the met tower should be moved to the Windy Ridge area (Option 3). While data was being collected at Option 2, PNNL recommended that FWA coordinate with stakeholders to gain approval to site a met tower at Windy Ridge.

The met tower installation near the CRTC test track was completed October 21, 2009 and data transmittal began October 22, 2009. The 1 year of data collection ended October 22, 2010.

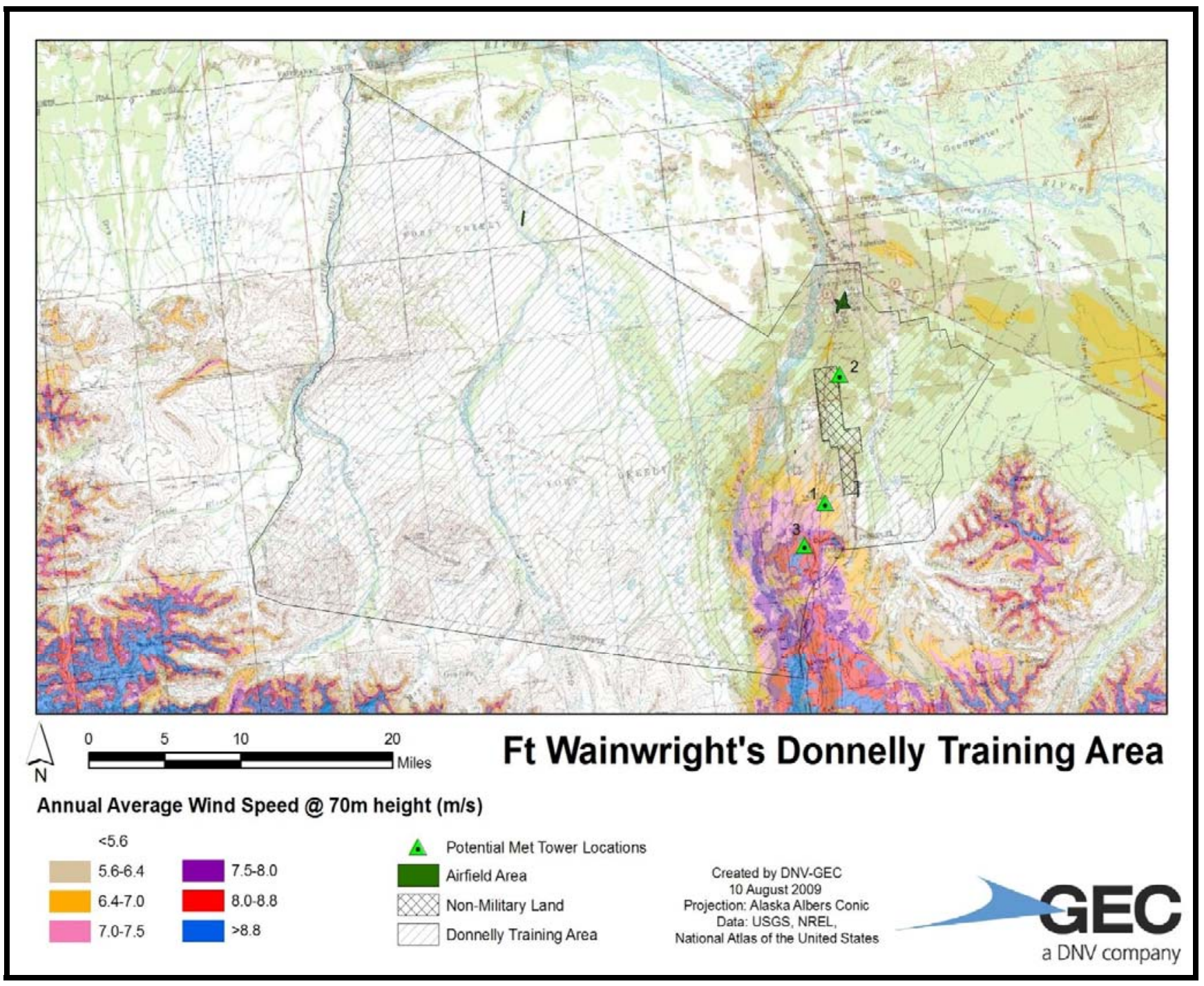

Figure 1. Donnelly Training Area Wind Resource 


\subsection{Wind Data}

The full wind data report is provided in DNV's Annual Wind Resource Data Summary. Table 1 presents the annual average and monthly average wind speeds provided in that report at each of the different anemometer height levels (DNV 2010).

Table 1. Monthly Wind Speed Averages in meters per second (m/s)

\begin{tabular}{|c|c|c|c|c|}
\hline \multirow{2}{*}{ Month } & \multicolumn{4}{|c|}{ Anemometer Heights } \\
\hline & $50 \mathrm{~m}$ & $30 \mathrm{~m}$ & $25 \mathrm{~m}$ & $10 \mathrm{~m}$ \\
\hline November 2009 & 5.1 & 4.6 & 4.6 & 3.8 \\
\hline December & 6.5 & 5.8 & 5.6 & 4.6 \\
\hline January 2010 & 4.9 & 4.3 & 4.4 & 3.8 \\
\hline February & 6.8 & 6.2 & 6.4 & 5.3 \\
\hline March & 6.2 & 5.7 & 5.6 & 4.7 \\
\hline April & 6.3 & 5.9 & 5.9 & 4.9 \\
\hline May & 4.9 & 4.6 & 4.5 & 3.8 \\
\hline June & 4.0 & 3.7 & 3.6 & 2.9 \\
\hline July & 5.4 & 5.1 & 5.0 & 4.0 \\
\hline August & 4.8 & 4.4 & 4.5 & 3.6 \\
\hline September & 4.1 & 3.7 & 3.7 & 3.0 \\
\hline October & 6.4 & 5.8 & 5.9 & 4.9 \\
\hline Annual Average & 5.5 & 5.0 & 5.0 & 4.1 \\
\hline
\end{tabular}

Because of icing of the anemometers, the overall data recovery rate was $85 \%$ for all anemometer heights (DNV 2010). To establish a wind resource characterization with low uncertainty and to secure favorable project financing, the industry preference is to see at least a $96 \%$ rate of data recovery and have a representative long-term data set. 
DNV's Annual Wind Resource Data Summary does not provide a representative long-term data set. The information provided in the annual data summary is based on the validated data, but does not include detailed analysis and should be considered preliminary. For example, invalid data, removed because of icing, was not replaced with appropriate estimates based on other sensors on the tower, correlations to other towers, or other data as appropriate. This type of additional analysis is required to establish a representative long-term data set.

According to the wind resource map in Figure 1, the met tower location is predicted to have an annual average wind speed of 5.6 to $6.4 \mathrm{~m} / \mathrm{s}$ at a 70 -m height above ground level. This represents the lower end of the DTA's potential wind resource range. The validated wind data confirms that the wind resource is low at this site, and perhaps lower than anticipated. An average wind speed of $5.5 \mathrm{~m} / \mathrm{s}$ at $50 \mathrm{~m}$ indicates the site has a high Class 1 to a low Class 2 wind resource. Class 1 and Class 2 wind resources are generally considered too low to support economically feasible wind energy projects.

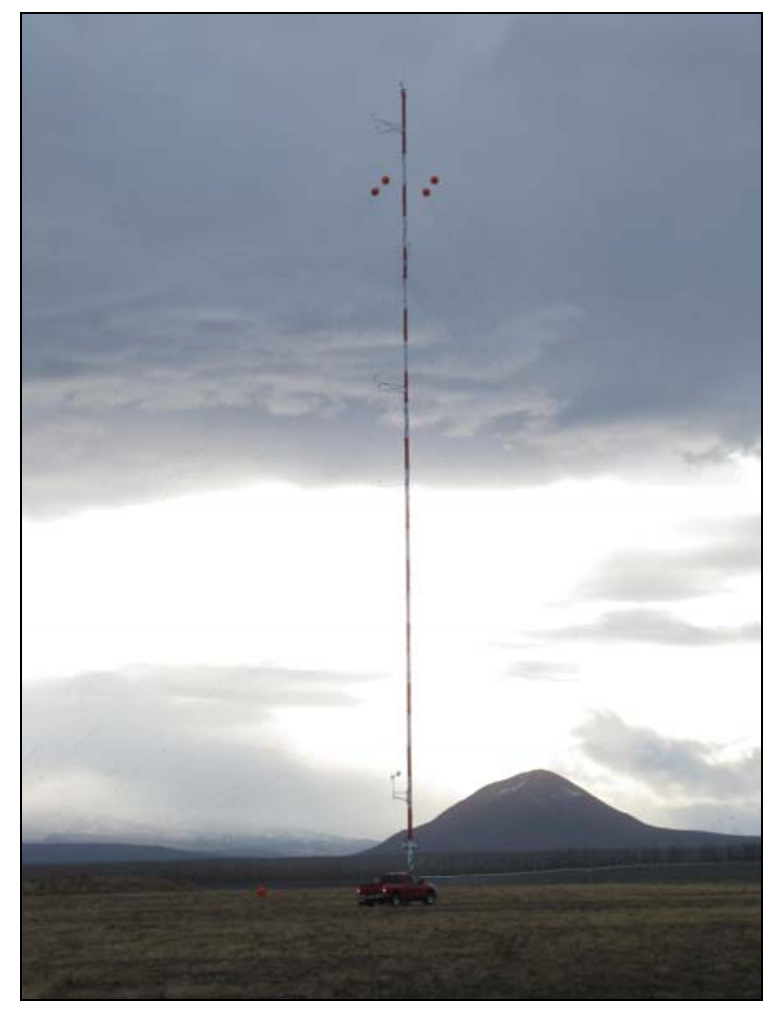

Figure 2. Met Tower 


\subsection{Turbine Options}

The goal of IMCOM-funded renewable energy assessment analyses is to identify economically feasible opportunities for generation of electricity from renewable resources - generation that is significant enough to warrant connection to the grid and/or to contribute in a meaningful way to the aggressive Energy Policy Act (EPAct) and Department of Defense (DOD) renewable energy goals. To support this, PNNL's assessments focus on projects with a size of at least $1 \mathrm{MW}$, and for wind energy projects, a 1.5-MW turbine model is used for project economic calculations.

In PNNL's renewable energy assessment report for Fort Wainwright, preliminary wind energy project economics were calculated based on wind map data from the Windy Ridge area and a 1.5MW turbine. Those calculations are not revisited for this report. Now that the wind resource at the selected site has been confirmed as low, and there has not been analysis done to predict the wind speeds at heights greater than the met tower height, there is little value in examining the estimated energy production for a large-scale turbine. Alternately, this report will examine the energy production from a $100-\mathrm{kW}$ turbine and a $900-\mathrm{kW}$ turbine. Ultimately, due diligence of a manufacturer's performance history and turbine site suitability studies are recommended when selecting a turbine model for a project.

Table 2 indicates the estimated gross and net energy productions that a 100-kW turbine model would have produced, exposed to the wind resource measured at the met tower location during the year of measurement. The calculations assume the turbine's standard atmospheric conditions power curve.

Table 2. 100-kW Turbine Energy Production Estimates

\begin{tabular}{|l|c|}
\hline & Northern Power Northwind 100 \\
\hline Standard Conditions & $1.255 \mathrm{~kg} / \mathrm{m}^{3}$ air density, 0 m above sea level \\
\hline Turbine Rated Capacity & $100 \mathrm{~kW}$ \\
\hline Turbine Hub Height & $37 \mathrm{~m}$ \\
\hline Average Annual Wind Speed & $5.2 \mathrm{~m} / \mathrm{s} \mathrm{at} 37 \mathrm{~m}$ \\
\hline Wind Shear Exponent, $30-50 \mathrm{~m}$ & 0.21 \\
\hline Estimated Gross Annual Energy Production & $224,644 \mathrm{kWh}$ \\
\hline Gross Capacity Factor & $25.6 \%$ \\
\hline Estimated Losses & $17 \%$ \\
\hline Estimated Net Annual Energy Production & $186,455 \mathrm{kWh}$ \\
\hline Net Capacity Factor & $21.3 \%$ \\
\hline
\end{tabular}

This turbine model typically has an installed cost of $\$ 550,000$ and annual operations and maintenance (O\&M) costs are expected to be about $\$ 0.01 / \mathrm{kWh}$ of energy production. 
Table 3 indicates the estimated gross and net energy productions that a 900-kW turbine model would have produced exposed to the wind resource measured at the met tower location during the year of measurement. The calculations assume the turbine's standard atmospheric conditions power curve.

Table 3. 900-kW Turbine Energy Production Estimates

\begin{tabular}{|l|c|}
\hline & EWT Direct Wind 54*900 \\
\hline Standard Conditions & $1.255 \mathrm{~kg} / \mathrm{m}^{3}$ air density, 0 m above sea level \\
\hline Turbine Rated Capacity & $900 \mathrm{~kW}$ \\
\hline Turbine Hub Height & $50 \mathrm{~m}$ \\
\hline Average Annual Wind Speed & $5.5 \mathrm{~m} / \mathrm{s}$ at $50 \mathrm{~m}$ \\
\hline Estimated Gross Annual Energy Production & $1,607,727 \mathrm{kWh}$ \\
\hline Gross Capacity Factor & $20.4 \%$ \\
\hline Estimated Losses & $17 \%$ \\
\hline Estimated Net Annual Energy Production & $1,334,413 \mathrm{kWh}$ \\
\hline Net Capacity Factor & $16.9 \%$ \\
\hline
\end{tabular}

A 900-kW turbine typically has an installed cost of $\$ 2,800$ to $\$ 3,100$ per $\mathrm{kW}$. An annual O\&M cost of $1 \%$ of the installed cost can be assumed.

While 37 meters is the standard hub height for the 100-kW turbine, hub heights of 35, 40, 50 and 75 meters are available for the $900-\mathrm{kW}$ turbine according to the manufacturer (EWT 2010). A 50$\mathrm{m}$ hub height was selected because that is the extent of the wind data available. Also, while a higher hub height would allow for increased energy production, it is reasonable to assume that there may be height limitations placed on a wind energy project sited in DTA because of air operations.

Net energy is gross energy minus any losses. Losses can typically reduce gross energy by between $12 \%$ and $25 \%$. Losses come from reduced availability, wake and array effects, turbine performance issues, electrical losses, and icing or other detrimental weather conditions. During the year of data collection, a significant amount of data was lost because of icing of the anemometers on the met tower, as heated anemometers were not used. It can be expected that a wind turbine would experience icing as well, and potentially have lost hours of energy production.

Cold weather modifications can be made to the tower and turbine design to mitigate the impacts of cold weather and icing on turbine performance. For example, a space heater can be added to the nacelle or blades can be painted black to increase their surface temperature to prevent icing. 


\subsection{Project Economics}

In PNNL's renewable energy assessment report for Fort Wainwright, various energy costs were identified. The energy costs relevant to this analysis are shown in Table 4.

Table 4. Energy Costs

\begin{tabular}{|c|c|}
\hline Energy Cost, $\mathbf{c} / \mathbf{k W h}$ & Explanation \\
\hline 5.64 & $\begin{array}{c}\text { Cost of energy from Fort Wainwright's coal- } \\
\text { fired plant minus wheeling charges }\end{array}$ \\
\hline 13.67 & $\begin{array}{c}\text { Direct energy cost to replace GVEA electricity at } \\
\text { Fort Wainwright minus wheeling charges }\end{array}$ \\
\hline
\end{tabular}

Wind power provides intermittent power, which may reduce demand costs but is assumed to only reduce direct energy costs. If power is wheeled from a project in Fort Wainwright's DTA to Fort Wainwright in Fairbanks, this wind power can either replace Golden Valley Electric Association (GVEA) electricity at $13.67 \$ / \mathrm{kWh}$ or power from the coal plant at $5.64 \mathrm{\Phi} / \mathrm{kWh}$. These are net value avoided costs because the wind project's revenue is the avoided cost minus any wheeling charges (the cost of getting the power to Fort Wainwright). These costs do not include wheeling charges because GVEA, not the project, would be the recipient of any wheeling compensation.

To examine the economic potential of these turbine options, the two options were evaluated for Energy Conservation Investment Program (ECIP) eligibility and independent power producer (IPP) project potential. To qualify for ECIP funding, a project must achieve a savings-toinvestment ratio (SIR) of 1.0, and its payback is also examined. For the IPP evaluation, the commercial cost of energy (COE) needed to obtain an internal rate of return (IRR) of $10 \%$ was calculated. This is assumed to be the minimum IRR required to attract the interest of a wind power project developer. Table 5 lists the assumptions and results of these analyses in 2010 dollars. 
Table 5. Economic Assumptions \& Results

\begin{tabular}{|l|c|c|}
\hline & $\begin{array}{c}\text { Northern Power } \\
\text { Northwind 100 }\end{array}$ & EWT DW 54*900 \\
\hline Project Size & $100 \mathrm{~kW}, 1$ turbine & $900 \mathrm{~kW}, 1$ turbine \\
\hline Installed Cost & $\$ 5,500 / \mathrm{kW}$ & $\$ 2,950 / \mathrm{kW}$ \\
\hline Annual Fixed O\&M Cost & $\$ 18.70 / \mathrm{kW}$ & $\$ 29.50 / \mathrm{kW}$ \\
\hline Federal Tax Rate & $35 \%$ & $35 \%$ \\
\hline State Tax Rate & $9.4 \%$ & $9.4 \%$ \\
\hline 5-year Accelerated Depreciation & Included & Included \\
\hline Federal Production Tax Credit & Included & Included \\
\hline Transmission Costs & Not Included & Not Included \\
\hline COE Required to Achieve a 10\% IRR & 37.1 \& $/ \mathrm{kWh}$ & $24.2 \Phi / \mathrm{kWh}$ \\
\hline ECIP Metrics @ 5.64థ/kWh & 0.2 SIR, 61 year payback & 0.4 SIR, 41 year payback \\
\hline ECIP Metrics @ 13.67థ $/ \mathrm{kWh}$ & 0.6 SIR, 25 year payback & 0.9 SIR, 17 year payback \\
\hline
\end{tabular}

The COE required to achieve a 10\% IRR for either turbine option is higher than Fort Wainwright's current energy costs. But the project economics of both turbine options are slightly more favorable when compared against the cost of replacing electricity from GVEA, than from coal generation. Given the cost and performance assumptions, the ECIP scenario for replacing GVEA electricity with the 900-kW turbine has the best potential. Changes to the assumptions could impact this result. For example, if the cost of electricity from GVEA has increased since PNNL first calculated the rate used in this analysis, that would favorably impact the ECIP metrics. Also, a higher hub height could increase the turbine's energy production which would improve the turbine's capacity factor and thus its project economics as well. 


\subsection{Delta Junction Wind Farm}

Outside of Fort Wainwright's DTA is the privately owned Delta Junction Wind Farm. It has one Northwind 100-kW turbine from Northern Power and one Directwind 900-kW turbine from EWT. The 100-kW was commissioned in October 2008 (AEP 2010) and the 900-kW turbine went online at the end of July 2010. The turbines are situated on a knoll that gives the site an elevation of 1,350 feet. The Fort Wainwright met tower site is approximately 800 feet in elevation.

In November 2010, the Delta Junction Wind Farm was experiencing wind speeds of between 10.6 and $13.4 \mathrm{~m} / \mathrm{s}$ at a height of $75 \mathrm{~m}$ on at least a few days. This site may have a higher wind resource than the Fort Wainwright site because of its elevation. However, average, annual wind speeds for the Delta Junction Wind Farm are unknown.

Mike Craft of Alaska Environmental Power (AEP), the owner of the wind farm, has shared some data with PNNL and Fort Wainwright about his turbines. Table 6 displays PNNL's estimations of the turbines' performance, based on the minimal data provided. Mike Craft told Fort Wainwright staff that the 900-kW turbine cost \$1.8 million and the overall installed project cost was about \$2.6 million ${ }^{1}$. This is a total installed cost of approximately $\$ 2,900 / \mathrm{kW}$.

Table 6. Delta Junction Wind Farm Energy Production Estimates

\begin{tabular}{|l|c|c|}
\hline & $\begin{array}{c}\text { EWT DW } \\
\mathbf{5 4} \mathbf{9 0 0}\end{array}$ & $\begin{array}{c}\text { Northern Power } \\
\text { Northwind 100 }\end{array}$ \\
\hline Turbine Rated Capacity & $900 \mathrm{~kW}$ & $100 \mathrm{~kW}$ \\
\hline Turbine Hub Height & $75 \mathrm{~m}$ & $37 \mathrm{~m}$ \\
\hline July 2009 Data & & \\
\hline Total Energy Produced & - & $77,404 \mathrm{kWh}$ \\
\hline Time Available & - & 5,508 hours \\
\hline Calculated Gross Capacity Factor & - & $14 \%$ \\
\hline November 2010 Data & & \\
\hline Total Energy Produced & $447,438 \mathrm{kWh}$ & $125,096 \mathrm{kWh}$ \\
\hline Time Available & $2,592 \mathrm{hours}$ & $7,781 \mathrm{hours}$ \\
\hline Calculated Gross Capacity Factor & $19 \%$ & $16 \%$ \\
\hline
\end{tabular}

These calculations provide just a snapshot of the turbines' energy productions. These calculations are based on the limited data provided ${ }^{2}$, and may not be an accurate representation of the project's overall, annual performance. AEP's website says the farm added $900,000 \mathrm{kWh}$ to the grid in 2009 (AEP 2010).

\footnotetext{
${ }^{1}$ Emails from Mike Craft to Ashish Agrawal shared with PNNL.

${ }^{2}$ Emails from Mike Craft to Ashish Agrawal shared with PNNL.
} 


\subsection{Fort Wainwright Energy Consumption}

When Fort Wainwright's steam turbines are not operating at full capacity, or there is excessive electricity demand on site, Fort Wainwright buys supplementary electricity from Golden Valley Electric Authority (GVEA). In FY 2008, GVEA supplied 11,578 MWh to Fort Wainwright, with a maximum demand of 8.5 MW. In FY 2007, however, GVEA supplied Fort Wainwright with $24,580 \mathrm{MWh}$ of electricity, with a maximum demand of $13.8 \mathrm{MW}$. The variation is primarily a function of generator operation. It is estimated that Fort Wainwright's typical demand is about 20 MW, although self-generated electricity is not metered and therefore an exact figure is unknown (Chvala et al. 2009).

In 2005, Fort Wainwright conducted a study of its existing loads and projected future loads. These projections are presented in Table 7 (Fort Wainwright 2005). Also in Table 7 are the electricity amounts, based on those projections, that need to be supplied by renewable energy, per the EPAct mandate and DOD goal.

Table 7. Fort Wainwright Projected Energy Consumption

\begin{tabular}{|c|c|c|c|}
\hline $\begin{array}{c}\text { 2013 Projected } \\
\text { Electricity Consumption }\end{array}$ & $\begin{array}{c}\text { Amount of Electricity } \\
\text { Required to meet 7.5\% } \\
\text { of 2013 Electricity } \\
\text { Consumption (EPAct } \\
\text { Requirement) }\end{array}$ & $\begin{array}{c}\text { Amount of Energy } \\
\text { Required to meet 25\% } \\
\text { of 2025 Electricity } \\
\text { Consumption (DOD } \\
\text { goal) }\end{array}$ \\
\hline $\begin{array}{c}\text { 160,000 MWh, } \\
29 \mathrm{MW}\end{array}$ & $\begin{array}{c}200,000 \mathrm{MWh} \\
37 \mathrm{MW}\end{array}$ & $12,000 \mathrm{MWh}$ & $50,000 \mathrm{MWh}$ \\
\hline
\end{tabular}

Using the estimated energy production calculations, Table 8 presents how many turbines of each model, and the project costs, it would require to meet the EPAct requirement and DOD goal.

Table 8. Wind Energy Requirements to Meet Goals

\begin{tabular}{|c|c|c|c|c|c|}
\hline Turbine & $\begin{array}{c}\text { Estimated Energy } \\
\text { Production per } \\
\text { Turbine }\end{array}$ & $\begin{array}{c}\text { Number of } \\
\text { Turbines Required } \\
\text { to Meet EPAct } \\
\text { Requirement }\end{array}$ & $\begin{array}{c}\text { Estimated Project } \\
\text { Cost to Meet } \\
\text { EPAct } \\
\text { Requirement }\end{array}$ & $\begin{array}{c}\text { Number of } \\
\text { Turbines Required } \\
\text { to Meet DOD Goal }\end{array}$ & $\begin{array}{c}\text { Estimated Project } \\
\text { Cost to Meet DOD } \\
\text { Goal }\end{array}$ \\
\hline $100 \mathrm{~kW}$ & $186 \mathrm{MWh}$ & 64 & $\$ 35,200,000$ & 268 & $\$ 147,400,000$ \\
\hline $900 \mathrm{~kW}$ & $1.33 \mathrm{MWh}$ & 9 & $\$ 23,895,000$ & 37 & $\$ 98,235,000$ \\
\hline
\end{tabular}

The large number of turbines required demonstrates that smaller turbines, or small projects in general, will not be sufficient in meeting renewable energy goals at Fort Wainwright. The project economics in Section 4 also demonstrate that the larger turbine option has better economics. 


\subsection{Recommendations}

Fort Wainwright should consider the costs and benefits of pursuing a single turbine installation and reuse the met tower in another location.

While the data collection has indicated there is a low wind resource at the CRTC test track location, a 900-kW turbine project there would have marginal economics and may be a possibility. An ECIP-funded 900-kW turbine that would replace energy purchased from GVEA provides the best economic potential with a 0.9 SIR and a 17-year payback, given the cost and performance assumptions. These ECIP metrics could improve if the cost of electricity from GVEA has increased since the rate was calculated for PNNL's renewable energy assessment report.

While the Army is strongly encouraging ECIP proposals for renewable energy projects, one 900$\mathrm{kW}$ turbine would not contribute significantly to Fort Wainwright meeting its renewable energy consumption mandates. And a multiple $900-\mathrm{kW}$ turbine project is unlikely to attract the interest of a third-party developer based on the high cost of energy it requires to achieve a $10 \%$ IRR. However, the neighboring Delta Junction Wind Farm has succeeded, and Fort Wainwright may benefit from that project's experience and knowledge.

Because sufficient met tower data has been collected at the CRTC test track site, PNNL recommends that Fort Wainwright move the met tower to another location to determine if a stronger wind resource is available somewhere else in the Donnelly Training Area. Two possible options are Windy Ridge and the Black Rapids Training Center.

Windy Ridge is indicated on the map in Figure 1 as site option 3 and was the site originally identified by PNNL in its assessment report as having high potential for a wind energy project because of the high expected wind resource of the area. According to the wind resource map, this area has an annual average wind speed of $7.0 \mathrm{~m} / \mathrm{s}$ or greater at a $70-\mathrm{m}$ height above ground level. The accuracy of this rating is unknown at this time. Strong, but inconsistent, winds in this area may skew the average annual wind speed indicated by the wind resource map. Mr. Egeland has indicated that this area receives strong Chinook winds from the south, but that these winds are inconsistent and only occur between $15 \%$ and $20 \%$ of the year. In addition, he says that Granite Mountain typically blocks the more consistent winds from the east. CRTC has no existing meteorological stations in this area.

The site is located west of Donnelly Dome, along the southern portion of Windy Ridge adjacent to a telecommunications station operated by AT\&T. Because of its elevation, this site will most likely require an archeological review. In addition, this site is on the edge of restricted air space. Range Control indicated that a minimum 300-m setback distance would be required from the restricted air space boundary.

Another possible location would be the Black Rapids Training Center. Fort Wainwright has received ECIP funding for a $200-\mathrm{kW}$ wind project at the Black Rapids Training Center. Depending on project and funding timing and weather, the met tower could be deployed to support this project. 


\subsection{References}

AEP - Alaska Environmental Power. 2010. Delta Junction Wind Farm. Accessed November 2010 at

http://alaskaenvironmentalpower.com/Alaska\%20Environmental\%20Power/Delta\%20Junction\%2 0Wind\%20Farm.html (last update unknown).

Chvala, Jr. WD, AR Kora, AC Orrell, BJ Russo, AE Solana, JC States, WM Warwick, MR Weimar, GK Bandyopadhyay, and DR Dixon. October 2009. Renewable Energy Opportunities at Fort Wainwright and Fort Greely, Alaska. Pacific Northwest National Laboratory, Richland, Washington.

DNV. 2010. Annual Wind Resource Data Summary, Fort Wainwright, Alaska, Data Summary and Transmittal for November 2009 - October 2010. DNV Renewables (USA), Inc., Seattle, WA.

EWT - Emergya Wind Technologies. 2010. Specifications DW 54-750 / 900 kW. Accessed December 2010 at http://www.ewtinternational.com/?id=47 (last update unknown).

Fort Wainwright. March 30, 2005. FWA CHPP Study 2005: Existing Loads and Load Forecast Analysis, Draft v.1. Provided by Alvin Kam, IMCOM-Pacific Region Energy Manager, on December 24, 2009. 



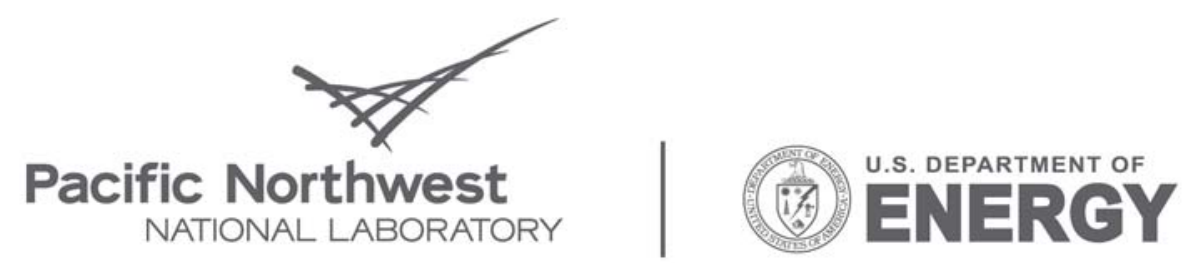

Proudly Operated by Battelle Since 1965

902 Battelle Boulevard

P.O. Box 999

Richland, WA 99352

1-888-375-PNNL (7665)

www.pnl.gov 